\title{
Applications Research of Creative Thinking in Teaching and Training of College Sports
}

\author{
Erxia Liu \\ Nanyang Institute of Technology, Nanyang, 473000, China
}

Keywords: College sports, Physical education, Creative thinking, Teaching and training

\begin{abstract}
College sports have far-reaching influence on students' future development, which is also an important part of China's innovation system. With the development of the times, the society pays more attention to the creative thinking of physical education. College physical education should infiltrate the creative thinking into all aspects of teaching and training. This paper expounds the existing problems and corresponding countermeasures in the applications of creative thinking in college physical education to provide some references for the relevant researchers.
\end{abstract}

\section{Introduction}

College sports teaching and training has received increasing attention, and promote the all-round development of College students. In order to improve the effect of college physical education teaching and training, college physical education teachers begin to apply creative thinking to teaching and training. With the use of creative thinking, the level of college sports teaching and training has also been improved, and has played an important role in the development of teaching. Creative thinking ability has its own characteristics, and its characteristics mainly include flexibility and innovation. These two points play an important role in the cultivation of students' thinking ability. In college physical education, the rational application of creative thinking can effectively improve the teaching effect. Physical education and training college is a very practical subject, in order to make the students' practice ability training to the maximum, requires the application of creative thinking and reasonable, which can effectively improve the students' thinking ability, so that students can solve the related problems in the teaching and training of students through the use of independent, creative thinking, can be more comprehensive understanding to the key content of sports teaching and training in the University, so that the students can understand the various key knowledge, so as to allow students to more actively participate in sports teaching and training, so that the effect of college sports teaching and training effectively highlights. Creative thinking in physical education is conducive to strengthening the role of physical education and improving the overall level. The use of creative thinking is conducive to the cultivation of students' interest in sports training and learning enthusiasm, which has a positive impact on promoting the level of sports teaching and training effect. The use of creative thinking enables students to play their subjective role fully, and students participate in physical training more actively.

\section{Existing Problems of Applications of Creative Thinking in College Sports}

Backward Teaching Concept. With the continuous development of teaching reform, the cultivation of divergent thinking has become a major educational goal, which is called a creative way of thinking. From the general situation, the majority of college sports teaching are not applied to creative thinking has not obtained the popularization and promotion of the students is difficult to get breakthrough and improve the way of thinking in the teaching of physical education. The reason is that, in terms of the degree of ideological understanding, part of the physical education teachers themselves does not pay attention to the effective use of creative thinking teaching methods, making 
the final application of poor results. Because the sports teachers in the ideological understanding of physical problems, the actual teaching process, lack of creative thinking to guide and inspire the teaching environment, it is difficult for creative thinking to rational use, play its due role, so that students cannot get profit from, thinking ability. Creative thinking mode has not been widely used in the current college physical education, which leads to the teachers and students did not pay enough attention to the application of creative thinking. Although many schools of the new curriculum reform comprehensively, but the teacher not fully understand and adapt to the new curriculum requirements, from the fundamental concept of teaching is confined to teach knowledge in teaching aspects, just pay attention to their leading role, not the main role of college students, teaching to instill the way, not really to teach the students to learn knowledge. As a guide, teachers cannot correctly recognize the importance of creative thinking, which leads to the application of creative thinking in college physical education is not ideal, and cannot play its due effect and role. Of course, in the sports learning and training, there is no awareness of cultivating their own innovative thinking ability, which also affects the normal play of creative thinking.

Serious Teaching Atmosphere. From the general situation, the current college physical education teaching does not involve the effective use of creative thinking. Most of the students in the physical education and enthusiasm is originally insufficient, plus enough attention to PE teaching environment is dull and boring, restricted the sports teaching and training learning effect. From the teacher's point of view, it is impossible to accurately understand and grasp the whole situation, so that the teaching practice of creative thinking cannot be truly implemented. Nowadays many colleges and universities will be teaching hardware facilities have largely improved and perfect, but it is easy to be ignored in the sports teaching facilities, such as land use in sports dressing, sports equipment, sports facilities for maintenance, even there are many schools for enrollment of students, the original sports activities site construction, students do not have the perfect sports facilities, sports venues and equipment, they are interested in sports cannot be carried out, this is a serious restriction of the launching of the new curriculum factors. Whether college physical education teachers or ordinary college students, for them, the acceptance and use of creative thinking requires a certain amount of time and space. Therefore, college PE teachers should learn more creative thinking activities, and refer to and learn from other colleges and universities sports teachers' successful experience, and strive to cultivate students' interest in learning. College students do not like the dull and boring sports class, but once PE teachers change the form of sports class, it is too relaxed, and it may have a negative impact. At the same time, the university physical education teachers should not only improve their interest in learning, but also enliven the classroom atmosphere.

Single Teaching Model. The cultivation of creative thinking is the process of long-term struggle, but due to creative thinking not get enough attention to physical education teachers in the university physical education, leading to creative thinking cannot play the role of university sports teaching and its effect. The students lose interest in learning, not actively cultivate students' divergent thinking the main reason is the single way of teaching, students cannot comprehensively, the level of creative thinking is limited and cannot achieve the desired effect. The training and mastering of creative thinking mode must first have the accumulation of long-term training experience, and get progress and improvement in the continuous reflection and summary. But unfortunately, the current development of university sports teaching management status, many sports teachers are serious drawbacks in consciousness, ignoring the creative way of thinking, the teaching mode is too old, single and fixed, already let the students have tired, led directly to the guidance of creative thinking mode had little effect. The main teaching methods used at present, for the students to answer questions in the form of praise and encouragement as the main method, has obvious limitations, only apply to the university sports teaching, and once in the actual sports training, but did not realize the guide and stimulate students' creative thinking target. It is affected by the single, lack of effective ways of teaching, the creative thinking of college students learning and training decreased enthusiasm to form independent thinking and independent learning, good learning habits and patterns, considers the problem of the lack of comprehensive, systematic, unable to complete the provisions of the new curriculum standards for college physical education requirements. 


\section{Countermeasures of Applications of Creative Thinking in College Sport}

Update Teaching Ideas. The effective implementation of physical training or physical education is closely related to creative thinking. The cultivation of innovative consciousness is the basis of creativity. Human behavior is guided by thought. Therefore, when we pay attention to the cultivation of innovation ability and the formation of a strong sense of innovation, innovative behavior will emerge. The process of physical education teachers should be enterprising and creative spirit in the sports training, combined with the needs of students and the needs of the times, constantly updating the teaching method, practice method of setting new teaching goals and innovative. At the same time, physical education teachers should create more opportunities for students to practice, so that students can both brains and hands, and in practice to find problems and solve problems. Let students challenge themselves in the competition, and dare to set higher goals. It also makes students realize that any sport is not a single sport. As long as we give full play to creativity, we can play out the original dull and dry sports, so as to cultivate students' innovative consciousness and make them good at thinking. Through their own creativity, sports will be processed and re-created, so as to achieve the purpose of exercising their innovative thinking in sports. Teachers should have a systematic understanding of creative thinking, and to the cultivation of creative thinking actively, improve their awareness of innovation, to clear the importance of creative thinking, which can be better applied to the university sports teaching and training in the university sports teaching and training effect can be improved. In the process of carrying out physical education and training, college PE teachers should pay attention to the cultivation of students' creative thinking, so as to continuously improve the students' learning ability, and then promote the all-round development of students.

Improve Teaching Environment. Creative thinking is divergent thinking. This way of thinking to get good application, but also need certain conditions. In the university sports teaching and training, we must have enough relaxed atmosphere classroom atmosphere, can make the creative thinking play its due role. And create a relaxed classroom atmosphere, make students classroom learning cannot relieve stress, but also can stimulate the enthusiasm of learning students effectively, so that the students can solve the problem, to find suitable solutions. This can train students' creative thinking. However, it is worth noting that the active classroom atmosphere, also need to strictly according to the teaching focus to carry out the control, as much as possible to the classroom atmosphere control within reasonable limits, based on active classroom atmosphere, so as not to make the classroom is too loose, so as to better protect the teaching effect of training. In order to enhance the thinking ability of students in sports teaching and training, optimize and improve the way of thinking, teachers should give students more affirmation and encouragement, to make it more active and positive, to develop good study habits. By encouraging and affirming the teacher timely and appropriately, the students can find their own advantages, at the same time, constantly reflect and summarize, perfect the deficiencies in time, accomplish the training purpose of creative thinking. Give students space to let them play, change the original fixed teaching mode, so as to enhance the students' interest in sports activities and team spirit, to cultivate the overall quality of the students, cultivate their consciousness of lifelong physical education, physical education in order to achieve. In the process of teaching, it is necessary for teachers to adopt diversified teaching methods to enrich their teaching content. The teacher in the teaching process of teaching difficulties in the course of the students targeted professor, also want to focus on the content in the sports teaching in the teaching of students, flexible teaching methods are combined, so as to enhance the quality of teaching. Give appropriate praise for outstanding students, and for learning does not accumulate the pressure pole and the results are not good enough students, also should be encouraged and willing to pressure, so as to stimulate students' learning enthusiasm and desire, strengthen confidence, the implementation of creative thinking exercise independently. For example: in a university, physical education teachers in track and field teaching and training process, let learning initiative to carry out creative thinking and analysis, in order to improve training action, find the best way for themselves. Combined with different periods of sports training, according to the different characteristics of each student, appropriate encouragement and praise, rekindle their learning morale, achieve training objectives. 
Enrich Teaching Models. In order to make the physical education and training college students can get the whole development, we need to develop the students' creative thinking, and in order to make the students creative thinking ability can be improved, you need to spend a lot of time to carry out the cultivation of college students, actively carry out the University Sports training, reasonable application of all kinds of university sports training the method, in the premise of cultivating students basic knowledge, hands-on practical ability for the students to effectively improve, focus on the cultivation of students' autonomous learning ability, so that it can be in the training process, to find out the suitable ways of training, effective play to the creative thinking, reasonable answers to various problems this, to exercise their comprehensive skills, the students' comprehensive ability training, which can highlight the students comprehensive training effect. In order to improve and enrich the sports courses in Colleges and universities, according to the requirements of the new curriculum standard, in the university sports curriculum structure in new elective content in the sports teaching content is more diversified more flexibility for students. Physical education activities in Colleges and universities in various areas of China can carry out proper physical education activities according to their own resources and their own conditions. After mastering the interest points of college students, we should optimize the teaching content and form in the way of scenario creation, and help students to participate in physical education and training. In this way, relying on Immersive teaching situation settings, so that students understand and master the basic sports knowledge, guide students to implement targeted training of creative thinking. Through the change of teaching methods, help students actively find and solve problems and deficiencies in the process of learning and training, and form good teaching effect. For example: the situation creation methods to make use of the fast running teaching curriculum, students are required to implement the training division and its around what can run faster the question guiding thinking in specific sports training practice, let the students in the actual situation of training, to find their own shortcomings, make up the defects as soon as possible so, the ultimate goal of teaching to help students enhance the creative ability.

\section{Conclusion}

The present college physical education teaching and training is not perfect, there are still many shortcomings and shortcomings. Therefore, in the future college students' sports teaching and training, university sports teachers play a vital role. Only when they change the traditional mode of thinking, can they provide more attractive sports teaching and training activities for the contemporary college students.

\section{References}

[1] Lin Yue. Research on the Innovation of College Physical Education Teaching from the Perspective of Internet Media [J]. Education Teaching Forum, 2017(2): 116-117.

[2] Liu Heng, Feng Ting. Sports Teaching Mode Based on Virtual Reality Technology of Practice and Thinking [J]. Journal of Beijing Normal University (Natural Science), 2013, 49(6): 649-652.

[3] Zheng Ying, Xie Huisong. A Rearch on the Theory Construction and Discussion of Creative Teaching Mode of Sports Courses in Colleges [J]. Journal of Beijing Sport University, 2009, 32(9): 68-71.

[4] Hui Qiuli. Analysis of creative thinking teaching mode under the background of physical education teaching reform [J]. Hunan Agricultural Machinery, 2013, 40(3): 191-192. 